\title{
Teaching Problems and Countermeasures Analysis of the Course of Chinese Modern Economic History in History Major
}

\section{Boli Ding}

Shangqiu Normal University, Shangqiu 476000, Henan, China.

\begin{abstract}
Chinese Modern Economic History is an interdisciplinary subject closely related to history and economics. The course of "Chinese Modern Economic History" set up by the history major of higher vocational education has an irreplaceable role in improving the subjectivity and independence of the subject, and is conducive to promoting the employment of students. However, with the in-depth reform of China's vocational education system, there are still many problems in the course that need to be resolved. This article focuses on the problems and countermeasures related to the teaching of the history of Chinese Modern Economic History.
\end{abstract}

Keywords: History Major; Modern Chinese Economic History; Curriculum Teaching; Problems and Countermeasures; Analysis

The research and teaching of economic history have a dual-orientation. All along, the teaching of economic history in vocational colleges has mostly focused on theoretical economic disciplines, and the history major has not received the attention it deserves. Next, this article will talk about some reflections on the teaching of Chinese Modern Economic History in the history major of vocational colleges.

\section{Problems in the teaching of Chinese Modern Economic History for history majors}

\subsection{Little research on the laws of the economy itself}

The courses of Chinese Modern Economic History in higher vocational colleges are mostly focused on the study of foreign capitalist invasion, and lack of research on the laws of the economy itself. For example, when explaining the knowledge of the Opium War, it is normal to analyze the impact of the invasion of foreign capitalism on China's economy at that time, but the textbook focuses on the greed of foreign capitalism and dumping of commodities, which involves fewer knowledge points on the development of China's commodity economy and the formation of a global market. Objectively speaking, China's feudal society is closed to the outside world. The development of foreign capitalism closely linked countries all over the world, speeding up the process of world integration. World trade is not only a basic condition for industrial development, but also a bridge between countries in the world. In order to closely connect production and consumption in different countries, the export of commodities and capital to China by modern foreign capitalism is the result of economic laws. Therefore, when explaining this course, teachers should focus on the role of economic laws.

\subsection{Over-emphasis on general evaluation of economic matters}

In the course of Chinese Modern Economic History in higher vocational colleges, facing new economic things, the current explanation only takes account of the nature of the matter in a one-sided manner whether it is feudalism or capitalism. There is no in-depth study of the impact of this economic thing on economic development and people's lives. The course pays more attention to the production relations in economic activities, neglects the importance of productivi-

Copyright $@ 2020$ Boli Ding

doi: $10.18282 /$ le.v9i6.1314

This is an open-access article distributed under the terms of the Creative Commons Attribution Non-Commercial License

(http://creativecommons.org/licenses/by-nc/4.0/), which permits unrestricted non-commercial use, distribution, and reproduction in any medium, provided the original work is properly cited. 
ty, and does not study the new processes and technologies produced in economic development.

\subsection{The curriculum has not yet formed an independent subject system}

The subject system of the course Chinese Modern Economic History has not yet well constructed, and the terms and concepts included in the course are derived from the political theory part. For example, when explaining the concept of "bureaucratic capital", in essence, the word change originated from Mao Zedong's mouth, mainly used to refer to the capital owned by the Kuomintang government and the capital owned by the Kuomintang big bureaucrats privately, and its political role. They are consistent and are used to suppress the Communist Party and the people. This is classified from a political perspective. However, economic history is a cross-disciplinary and systematic discipline and cannot be so simply defined, because the property rights of the capital owned by the Kuomintang government and private capital owned by the Kuomintang bureaucrats are different, although they all suppress the Communist Party. There are many differences. If the analysis in the course of Chinese Modern Economic History is not clear enough, it is easy to cause ambiguity and patterns of concepts, resulting in the inability to reflect the characteristics of the course. The two courses Chinese Modern Economic History and Chinese Revolution History have similar terms, content, even the curriculum system, which largely indicates that the Chinese Modern Economic History course has abandoned some special content of the subjects, resulting in poor teaching quality and level.

\subsection{Always focus on service policies}

The original intention of the Chinese Modern Economic History of higher vocational colleges is to carry out political education. Therefore, the content has a strong political nature. The courses are directly related to the economic policies issued by Manqing, Beiyang or the National Government. It was denied and there was no in-depth analysis from an economic perspective. For example, the content of the currency reform of the Kuomintang government mentioned in the textbook: "In November 1935, under the planning of imperialism, the Chiang Kai-shek government implemented a 'currency reform', which stipulated that all future taxes and company payments should only use the 'fiat currency' issued by Jiang Bank, and declared that silver is 'state-owned'. In this way, they robed the country's bank deposits into their own hands." From an economic point of view, the conversion of metal currencies to credit currencies is the inevitable trend of economic development and currency development. Although the currency reform of the Kuomintang government oppressed the people, from an economic perspective, this is a manifestation of social and economic progress. In this case, it can be said that this is not conducive to improving the effectiveness of curriculum teaching.

\section{Specific countermeasures for the innovative teaching of the Chinese Modern Economic History}

\subsection{Clear teaching goals}

Chinese Modern Economic History is an important course for history majors. In the teaching process, teachers should adhere to the principle of "smart learning history" and through the course teaching, let students grasp the laws and characteristics of modern social and economic development in China, deeply comprehend the Chinese Communist Party's policy of government, the connotation and spirit of Marxist economic theory, and the superiority and the inevitable development of China's socialist modernization. Teachers should guide students to correctly understand the structure of modern Chinese semi-colonial and semi-feudal socio-economic attributes, and thus realize the relationship between productive forces and production relations, and improve the consciousness of safeguarding socialism with Chinese characteristics.

\subsection{Taking economic theory as the teaching entry point}

For higher vocational students, economic theory is very unfamiliar, but the economic theory is one of the cores in Chinese Modern Economic History. To improve the quality and level of curriculum teaching, economic theories must be used as the starting point. When conducting teaching, teachers should integrate some professional terminology, economics principles and other content to lay a solid foundation for subsequent in-depth learning. First of all, it is necessary to guide students to fully grasp the concepts, research objects and scope of economics and economic history, to make students correctly understand the importance and practicability of history, thereby imparting related historical theories 
and historical-philosophical issues and guiding students to fully grasp the relevant historical materials concepts. When explaining the relevant knowledge of economic theory, teachers should adopt the historical method, specifically, use the brief history of economic thought to draw out the basic theory of mainstream economics or the related objections to these theories, so that students can correctly understand economics theory is dynamic rather than static, changing rather than unchangeable. Economic thinking is all about solving the current special economic problems. Furthermore, for vocational students, it is more acceptable and cordial to use historical methods.

\subsection{Take the general economic history as the teaching support}

After explaining the economic theory, teachers should introduce some historical facts of economic development to students as the support of economic theories. This part is very important. As we all know, history is made up of facts, and it is impossible to conduct in-depth research without knowing the historical facts. As a vocational student, it is very important to consolidate the learning foundation. Therefore, guiding students to grasp the historical implementation is closely related to the students' deep development and career growth. In the process of explaining historical facts, teachers should focus on general history and guide students to view historical facts from a global and dynamic perspective based on the concept of holistic and time series, which is more conducive to the introduction of economic theory. In the process of explaining historical facts, the economic, political, military, cultural, and social levels can be comprehensively linked together, thereby improving the thoroughness and depth of explanation.

\subsection{Improve by reading classic literature}

The purpose of explaining the general history of the economy is to lay a solid foundation for students' learning. However, many modern vocational colleges only explain the basic knowledge of modern economic history, and the curriculum design cannot cultivate students' research capabilities. Therefore, after explaining the general history, teachers should improve class effectiveness through the introduction of classic documents. In terms of document introduction, it can be combined with the division of different topics such as industry, agriculture, commerce, transportation, etc. to explain in depth, so that it can achieve close cooperation with the previous link and make up for the shortcomings of the general explanation. In addition, the introduction of literature in the form of special topics is helpful for students to reach the forefront of academics and recognize some controversial issues. Then, teachers should guide students to think independently and to conduct in-depth research and study.

\section{Conclusion}

In summary, Chinese Modern Economic History is a vital part of the history of higher vocational education. Teachers should correctly recognize the importance of the course and combine the current teaching status quo to innovate teaching models and methods, so that students can obtain the most effective knowledge in the best way.

\section{References}

1. Yan P. Discussion on the problems of the elementary courses of modern Chinese economic history. Teacher Education Forum 2017; (003): 89-91, 96.

2. Ye Y. Problems and countermeasures in the teaching of Outline of Chinese Modern History. Hubei Today 2015; (006): 109-109.

3. Zhang L. Some thoughts on the construction of the undergraduate course of Chinese environmental economic history. Science and Education Wenhui 2018; 424(06): 42-43+60. 